\title{
THE CHEQUERED CAREER OF GALEN'S DOCTRINE ON THE PULMONARY VEINS
}

\author{
by \\ JEROME J. BYLEBYL AND WALTER PAGEL
}

By its heat and continuous motion, the lung further concocts the blood brought to it through the arterylike vein [pulmonary artery], and renders it foamier, such as that [blood] already is which reaches the lung through the veinlike artery [pulmonary vein] from the left ventricle of the heart, since it has already been elaborated in both ventricles of the heart. [Our italics]

Vesalius, Fabrica, 1543, p. 596.

IN HOLDING that arterial blood passes from the left ventricle of the heart into the pulmonary veins for consumption by the lungs, Andreas Vesalius aligned himself with many of the Galenic commentators of the preceding ages, but probably unwittingly against Galen himself. Galen did teach that the lungs draw nutriment from both pulmonary vessels, but he thought that the arterial blood in the pulmonary veins is derived from the pulmonary arteries rather than from the left ventricle. In view of the intrinsic interest of this topic as well as its possible bearing on the discovery of the pulmonary transit, we thought that it might be worthwhile to consider the views of the later authorities on this matter in relation to Galen's original teachings, in an effort to understand the discrepancy between the two. There were, of course, numerous other points of unconscious disagreement between Galen and his later followers, and hopefully this study will serve as an illustration of the more general process by which Galen's rather complex doctrines were interpreted and simplified by the men of succeeding ages.

This difference over the source of the arterial blood in the pulmonary veins probably reflects a more general difference between Galen and many of the later Galenists concerning the source of arterial blood. In Galen's view the blood of the arteries could be derived from the vrins through peripheral anastomoses, rather than from the left ventricle of the heart, and still be perfectly good arterial blood. ${ }^{1}$ This was because the arteries selectively take up only the lightest portions of the venous blood, and it was this difference in consistency that above all distinguished the two kinds of blood. The later Galenists, by contrast, tended to think of arterial blood as a unique product of the left cardiac ventricle, just as venous blood is of the liver. ${ }^{2}$ Therefore they probably had a strong predisposition to think that the arterial blood of the

${ }^{1}$ Galen, On the natural faculties, III, xiv; tr. A. J. Brock, London, 1952, pp. 315-19. Here he states explicitly that only some of the arteries of the body depend upon the heart for their blood.

2 See, e.g., Pietro d'Abano, Conciliator, Venice, 1565, Diff. XXXI, prop. i, fol. 48v: 'Sanguis ratione, continentis duplex est in praesenti: unus siquidem arter ialis, seu vitalis appellatus, a corde nascens \& per arterias $a b$ eodem ortas in totum diffunditur corpus: alter vero naturalis dictus, sive venalis generatus in hepate, a quo per venas in totum corpus dirigitur.' See also Girolamo Capivaccio, De anatomica methodo commentarius in Opera omnia, Frankfurt, 1603, p. 173. 


\section{J. J. Bylebyl and Walter Pagel}

pulmonary veins must come from the left ventricle, though this misinterpretation was greatly facilitated by the complexity and ambiguity of Galen's discussion of this particular subject. It is with these more specific aspects of the problem that we shall be primarily concerned.

Because of its predominant influence over later writers, we shall largely confine our discussion to Galen's treatise On the usefulness of the parts especially books six and seven where he treated the heart and lungs, respectively. ${ }^{3}$ There are some discrepancies between this and other Galenic works concerning the pulmonary veins, ${ }^{4}$ but to our knowledge he did not refer elsewhere to a flow of blood from the left ventricle into these vessels. Like many other readers we have studied the De usu partium as a source of Galen's physiological teachings, but it is necessary to bear in mind that the work was primarily intended to be an exposition of teleological anatomy rather than of physiology. That is, the chief aim of the treatise was to demonstrate that every part of the body had been ideally constructed to fulfil its purposes, and Galen therefore discussed function only to the extent that it had a bearing on structure. Thus the main focus of his discussion of the pulmonary vessels was, Why have they been constructed as they were? rather than, What are their functions?

According to Galen, the function of the pulmonary artery is to convey nutritive blood from the right cardiac ventricle to the lungs. ${ }^{5}$ In recognition of its nutritive function but arterial structure, Galen accepted the traditional designation 'arterylike vein' for this vessel.

His views concerning the pulmonary veins, which he called the 'veinlike arteries' because of their venous structure but pneumatic functions, were considerably more complex, though they can be grouped under three main headings. First, the pulmonary veins serve as ventilating ducts through which the left cardiac ventricle inhales cool air and exhales heated air and smokey vapours, just as the lungs inhale and exhale through the trachea. ${ }^{6}$ The purpose of this ventilation is to sustain the innate heat, located primarily in the left ventricle. Second, the pulmonary veins convey from the lungs to the heart a certain amount of air which is perfected into pneuma and distributed through the arteries, just as the mesenteric veins convey chyle from the intestines to the liver, where it is perfected into blood and distributed through the veins. ${ }^{7}$ The left ventricle also supplies the arteries with blood which it derives from the right ventricle through minute pores in the intervening septum. ${ }^{8}$ The third point, the one with which we are primarily concerned, is that the pulmonary

- For other discussions of these passages, see Leonard G. Wilson, 'Erasistratus, Galen, and the pneuma', Bull. Hist. Med., 1959, 33, 305-10, and A. Rupert Hall, 'Studies on the history of the cardiovascular system', Bull. Hist. Med., 1960, 34, 392-93, 399-407. Page references for the De usu partium will be to Margaret T. May's recent English translation, On the usefulness of the parts of the human body, 2 vols., Ithaca, N.Y., 1968, though in the preparation of this account frequent reference was made to the Greek text in Helmreich's edition (2 vols., Leipzig, 1907 and 1909).

' See Wilson, 'Erasistratus', pp. 302-3, 305-6, 309.

- De usu partium, VI, xi; tr. May, p. 306. In referring to the pulmonary vessels in this paper, we have generally used the modern terms 'pulmonary arteries' and 'pulmonary veins' except where it seemed essential to the sense of an argument to retain the Galenic terms 'arterylike veins' and 'veinlike arteries'. We also refer to 'lungs' in the plural rather than Galen's singular. In all direct quotations, however, we have left the original terminology intact.

'Ibid., VI, ii, xv; VII, ix; tr. May, pp. 280-81, 318, 351. See also Wilson, 'Erasistratus', pp. 310-14.

$?$ De usu partium, VII viii; tr. May, pp. 346-47. See also VI, ii and xvii, pp. 280, 324-25.

Ibid., VI, xvii; pp. 323-25. 


\section{The Chequered Career of Galen's Doctrine on the Pulmonary Veins}

veins contain arterial blood which is consumed by the lungs as a supplement to the blood brought by the pulmonary artery. ${ }^{9}$ Galen viewed this as part of a more general process whereby the arterial blood supplements the venous blood in the nutrition of the body, though there were certain peculiarities in the lungs reflecting their uniqueness among the parts of the body.

Galen began his discussion of the pulmonary vessels in the De usu partium with a favourite theme of his, namely that the right ventricle of the heart is a specialized structure for providing nutritive blood to the lungs and therefore does not exist in animals which do not have lungs. ${ }^{10}$ In such animals the single cardiac ventricle corresponds to the left ventricle of lunged animals. The right ventricle takes nutritive blood from the vena cava when it dilates, gives it an additional concoction, and expels it into the pulmonary artery when it contracts. Thus as Galen said there is a reciprocity between the heart and lungs in that the lungs supply air to the heart while the heart supplies nutritive blood to the lungs. ${ }^{11} \mathrm{He}$ clearly meant that these exchanges take place through the pulmonary vein and pulmonary artery, respectively.

In justifying this arrangement for nourishing the lungs, Galen's problem was to show that it was better than simply having the vena cava extend a branch to the lungs as it does to all the other parts. ${ }^{12}$ His strategy was to demonstrate that the nutritive vessel of the lungs, unlike the veins of the other parts, had to have thick tunics and have its mouth controlled by a one-way valve, and then to argue that a vessel with such tunics and such a valve could not simply arise from the thin-walled vena cava. Therefore the right ventricle was created as an intermediary, capable of giving rise to an arterylike vein and of providing firm support for a valve. As a corollary, Galen discussed the question of why the pneumatic vessels of the lungs (modern pulmonary veins) had to have thin tunics, unlike the arteries of the other parts of the body.

Galen said that before discussing the reasons for the reversal of the tunics of the pulmonary vessels, one must first know why it is that elsewhere veins have thin tunics and arteries thick ones. ${ }^{13}$ This is because the blood of the veins is a thick and sluggish' substance which could not reach the parts in sufficient quantity if it were contained in thick-walled vessels, while the pneuma of the arteries is quite subtle and would escape too rapidly were it not restrained by the denser arterial tunics. In accounting for the reversal in the lungs, Galen explained that the basic function of the latter is to dilate and contract in response to the motions of the thorax in order to alternately fill their arteries with air and then empty them. Thus it was good for the arteries ${ }^{14}$ to have thin tunics in order to respond to this dilatation and contraction as quickly and fully as possible, but if the veins of the lungs were also to dilate and contract in response to this motion they would detract from the filling and emptying of the arteries. Therefore these veins (modern pulmonary arteries) had to have thick tunics in order to be as resistant as possible to dilatation and contraction.

But if all other veins are thin-walled to let sufficient blood reach the parts, then it

- Ibid., VI, $x$ and VII, viii; pp. 299, 348-49.

${ }^{10}$ Ibid., VI, ix; pp. 295-96.

11 Ibid., VI, x; p. 296.

12 Ibid., pp. 296-97; see also VI, xi; pp. 304-6.

18 Ibid., VI, x; pp. 297-98.

14 Galen seems to be referring here to the veinlike arteries (modern pulmonary veins), though as we will see in book seven of the De usu partium he denied that these vessels dilate and contract with the lungs. 


\section{J. J. Bylebyl and Walter Pagel}

might seem that the lungs would suffer from having to draw their blood from a thickwalled vein. Galen solved this difficulty by recalling his doctrine that the nutritive requirements of the parts of the body vary according to the density of their substances. ${ }^{15}$ Nature provided for these individual needs by having the arteries contain, in addition to pneuma, a certain amount of blood which is much lighter than the blood of the veins, so that each part can absorb the thicker venous blood and the thinner arterial blood in a proportion that suits its particular requirements. Most parts of the body are rather dense, and so it is appropriate that their veins have thin tunics and their arteries thick ones so that they receive a maximum of 'thick and muddy' venous blood and a minimum of light arterial blood. The lungs, however, have a lighter substance than any other parts of the body and could not be suitably nourished by ordinary venous blood. Thus it was all to the good that their veins have thick tunics, which retain the blood until it has reached the thinness of arterial blood through additional concoction, and can then be absorbed by the lungs. Furthermore, while the thickness of the venous tunics may limit the amount of nutritive blood that can reach the lungs, this is compensated for by the thinness of the walls of its arteries (modern pulmonary veins), which thereby supply the lungs with an unusual abundance of light spirituous blood. These are important points, namely that thin blood is contained in the veinlike arteries (modern pulmonary veins) and that its purpose is to be absorbed by the lungs as a supplement to the thicker blood in the arterylike veins (modern pulmonary arteries). The clear implication is that the blood of the former vessels, unlike that of the latter, has already reached a state of perfection and therefore does not need to be restrained by thick tunics from premature absorption by the lungs.

Several additional factors also compensate for the diminished availability of blood to the lungs resulting from the arterial character of their veins. ${ }^{16}$ First, the arterylike vein is proportionally a very large one, thus partially making up by its size what is lost through the thickness of its walls. Second, the great heat in the region of the lungs greatly speeds the elaboration of the blood, thereby enabling it to escape from its vessel more quickly than usual. Third, the active dilatation of the lungs gives them additional power to draw blood out of a thick-walled vessel. Finally, and most important, the blood sent into the lungs is not ordinary venous blood because 'the lung is the only part to which the heart sends blood which it has already perfectly elaborated and attenuated.'

From the context it seems clear that the latter statement, like the first three, refers to the blood sent into the pulmonary artery by the right ventricle. Yet there seems to be a conflict between the idea that this blood is 'already perfectly elaborated' as it leaves the heart and Galen's previous assertion that the blood of the pulmonary arteries requires additional elaboration in the lungs before it can be absorbed by the latter. The contradiction seems less serious if we bear in mind that it was relative to the nutritive blood of the other parts that Galen described the blood expelled by the right ventricle as perfectly elaborated, while it was relative to the nutritive requirements of the lungs, the lightest parts of the body, that he described the same blood

${ }^{15}$ De usu partium, VI, x; pp. 298-300. See also VI, xvii; pp. 321-23.

${ }^{16}$ Ibid., VI, x; p. 300. 


\section{The Chequered Career of Galen's Doctrine on the Pulmonary Veins}

as still being too thick. Nevertheless, to a number of later men a more satisfactory way of resolving the contradiction was to suppose that this and other similar descriptions of a flow of perfectly concocted blood from the heart to the lungs referred to a flow of arterial blood from the left ventricle into the pulmonary veins. ${ }^{17}$

Thus Galen felt that he had established his first major point, namely that both the operation and nutrition of the lungs were better served by giving its vein the tunics of an artery. He then went on to try to show why the mouth of this vein had to be controlled by a one-way valve, which allows materials to enter the vessel from the heart but not to return. ${ }^{18} \mathrm{His}$ basic reason was that while the thick walls of the vessel help to prevent it from being compressed when the lungs contract, they cannot do so completely, so that if the pulmonary orifice were unprotected then each time the lungs contract some of the blood from the arterylike vein would be squeezed back into the right ventricle. This motion would be undesirable for three reasons. First, it is simply useless and inappropriate for blood to undergo a repeated flux and reflux between the right ventricle and lungs in this way. Second, by allowing the arterylike vein to yield to the pressure of pulmonary contraction, this reverse flow would detract from the degree of compression undergone by the arteries of the lungs at this time. Third, in the absence of the pulmonary valve the passage of blood from the fine ends of the arterylike veins (modern pulmonary arteries) into those of the veinlike arteries (modern pulmonary veins) would be inhibited.

It is this third point which is of particular interest to us. Galen prefaced his explanation of it by once again recalling one of his more general teachings about arteries and veins, namely that throughout the body they are joined by minute anastomoses through which the veins receive a certain amount of pneuma from the arteries and the arteries take up some blood from the veins. ${ }^{19}$ Similar connections exist between the vessels of the lungs, Galen said, but blood would not pass through them from the arterylike veins to the veinlike arteries were it not for the existence of the pulmonary valve. This is because materials escape from a compressed vessel more readily through a large opening than through small ones, so that if the way were open for blood to return to the right ventricle, then when the arterylike veins are compressed by the contraction of the lungs the blood would follow this path of escape in preference to passing through the minute connections with the veinlike arteries. As it is, however, the valve cuts off the return to the heart and so each time the arterylike veins are compressed there is no alternative but for a small amount of their blood to be squeezed into the fine ends of the veinlike arteries.

What is the purpose of this passage of blood from the arterylike veins to the veinlike arteries? Galen's only explicit statement is the following: 'Perhaps it is already clear to you what an excellent thing this is for the lung, if you remember what $I$ have said

17 Other such statements occur in ibid., IV, xv; p. 234: 'For it [the lung] is nourished by blood that is perfectly pure, bright red, thin, and spirituous; indeed, those advantages are inherent in the blood sent to the lung from the heart', and VI, xvii; p. 325: 'Since the substance of the heart is thick and dense and needs thicker nutriment, it is nourished by blood from the vena cava before it enters the heart; for when it arrives there the blood will have to become warm, thin, and spirituous .... It will be found to be most logical that the heart prepares nutriment for the lung, but not for itself; for the lung requires thin, spirituous blood, but the heart does not.' In this passage it is particularly clear that he is referring to the blood expelled by the right ventricle as thin and spirituous.

18 Ibid., VI, $x$; pp. 300-3.

19 Ibid., pp. 303-4. See also VI, xvii; pp. 321-24. 


\section{J. J. Bylebyl and Walter Pagel}

about its nourishment, but in case you do not, I shall explain it after I have finished the whole subject now before us.' 20

His meaning is not entirely clear, but it seems highly probable that he refers here to his view that the veinlike arteries contain arterial blood which is absorbed by the lungs as nutriment, an idea which he had explained shorty before and to which he did return in book seven of the De usu partium. ${ }^{21}$ Thus he seems to be telling us that the blood which the lungs take up from the veinlike arteries (modern pulmonary veins) is derived from the arterylike veins (modern pulmonary arteries) through the anastomoses between the vessels.

There might seem to be an inconsistency between Galen's belief that the blood of the veinlike arteries requires no further elaboration prior to being absorbed by the lungs and the idea that this blood is derived from that of the arterylike veins, which does require further elaboration. The conflict may not be a real one, however, for in his general discussion of the matter in the Natural faculties Galen made it clear that arteries do not draw blood through the anastomoses from the veins indiscriminately, but selectively, taking only the lightest portions of the venous blood. ${ }^{22}$ Thus we may suppose that it is only after being sufficiently attenuated in the arterylike veins that blood is squeezed through the minute anastomoses to the veinlike arteries. Once again, however, this resolution of the difficulty is by no means obvious, and some later men apparently reasoned that since the blood of the arterylike veins is relatively thick while that of the veinlike arteries is relatively thin, the latter must come from the left cardiac ventricle, which contains arterial blood.

Taken altogether, then, Galen's theory of the nutrition of the lungs would be the following: in dilatation, the right ventricle of the heart draws in blood from the vena cava which it elaborates by its heat, and in contraction it expels this blood into the arterylike vein (modern pulmonary artery). There the blood is further attenuated until it can pass through the thick tunics of the vessel and thus be absorbed by the lungs as nutriment. However, some of this blood is not taken up directly from the arterylike veins but is squeezed through the anastomoses to the veinlike arteries (modern pulmonary veins), from which it too is absorbed by the lungs. This scheme closely parallels Galen's description of the nutrition of the spleen in book four of the De usu partium: nutritive material reaches that organ through the splenic veins, from which one portion is taken up directly by the spleen, while another portion passes to the splenic arteries, from which it too is subsequently absorbed by the spleen. ${ }^{23}$ There is, we believe, little justification for the contention that Galen's description of the pulmonary anastomoses implies an awareness of the pulmonary transit as a functional concept, that is, as a pathway from the right cardiac ventricle to the left. ${ }^{24}$ The question

\footnotetext{
${ }^{20}$ Ibid., p. 304.
}

"Ibid., VII, viii; pp. 348-49. In VI, xxi, p. 321. Galen stated once again that the pulmonary veins derive blood from the pulmonary arteries through minute anastomoses.

"sa See note 1 above.

23 De usu partium, IV, xv; ed. Helmreich, vol. 1, p. 234. The point that the thin but dark blood of the splenic arteries is formed from material in the splenic veins is obscured somewhat in Mrs. May's translation.

" Leonard G. Wilson, 'The problem of the discovery of the pulmonary circulation', J. Hist. Med., $1962,17,229-31$, reaches a similar conclusion. The idea that Galen did know of the pulmonary circuit has been maintained by G. Ceradini, Qualche appunto storico-critico intorno alla scoperta della circolazione del sangue, Genoa, 1875, pp. 27-28 and passim, and more recently by Rudolph E. Siegel, 


\section{The Chequered Career of Galen's Doctrine on the Pulmonary Veins}

of whether his statements influenced the development of this idea by later men is, of course, quite a different matter, about which we shall have more to say below.

Following his special treatment of the right ventricle and pulmonary vessels, Galen went on to a more comprehensive treatment of the heart, with emphasis on the importance of its four valves. ${ }^{25} \mathrm{He}$ noted that three of the latter are composed of three membranes each, with the result that they are fairly efficient in preventing the regurgitation of materials which have passed through them, though a certain amount of leakage does occur. Only the mitral valve is composed of two membranes, however, and is therefore incompetent to a significant degree, 'because it was better that this one alone should give access to the lung for the fuliginous residues from the heart which necessarily accumulate there on account of the abundance of the innate heat and which therefore have no other, shorter outlet.' Thus in accordance with his view that the left ventricle ventilates itself by inhaling and exhaling through the pulmonary veins Galen made allowance for some reverse flow through the mitral orifice, though his failure to mention a flow of blood from the left ventricle into the pulmonary veins in this context casts further doubt on the idea that he himself envisioned such a flow. ${ }^{26}$

After discussing the heart in book six of the De usu partium Galen went on to treat the lungs in book seven, and here we find additional statements about the pulmonary veins. Once again, the chief function of these vessels is to convey air or pneuma from the lungs to the heart both for the sake of ventilation and for distribution through the arteries, and to convey fuliginous residues from the left ventricle to the lungs. ${ }^{27}$ Galen also insisted several times that the pulmonary veins contain spirituous blood which serves to nourish the lungs, stating at one point that the amount of this blood is 'not small' and at another that 'much' blood is absorbed by the lungs from these vessels. ${ }^{28}$

Galen's final discussion of the pulmonary vessels presents some difficulties of interpretation, in part because it is a summary of ideas set forth in his treatise $O n$ the motions of the thorax and lung which is no longer extant. ${ }^{29}$ Furthermore, it seems to conflict with his argument in book six that the pulmonary veins, unlike the pulmonary arteries, had to have thin tunics so that they could respond more easily to the motions of the lungs. For now in book seven Galen wished to show that neither the pulmonary arteries nor the pulmonary veins, but only the trachea and its branches, are affected by the motions of the lungs. The pulmonary arteries are completely motionless, while the motions of the pulmonary veins follow the rhythm of the heart,

\footnotetext{
'The influence of Galen's doctrine of pulmonary bloodflow on the development of modern concepts of circulation', Sudhoffs Arch. Gesch. Med., 1962, 44, 311-32. Siegel is able to cite only one place where Galen refers to a flow of blood from the pulmonary veins into the left ventricle (p. 312, referring to De usu partium VI, xxi; tr. May, p. 330), but it seems to us that Galen here refers to the foetal heart, not that of the adult, and that the blood in question enters the pulmonary veins (and left atrium) from the foramen ovale, not from the pulmonary arteries. See further discussion in W. Pagel's essay review of May's translation, Med. Hist., 1970, 14, 406-8.

${ }^{25}$ De usu partium, VI, xiv-xvi: tr. May, pp. 314-21.

26 Moreover, in ibid., VI, xx, p. 318, Galen states that very little material could pass from the heart to the lung through the mitral valve even if it were necessary.

27 Ibid., VII, viii-ix, pp. 345-51.

se Ibid., VII, iii, viii, pp. 337, 345-49.

20 Ibid., VII, ix, pp. 349-51; see also VII, iv, pp. 338-39.
} 


\section{J. J. Bylebyl and Walter Pagel}

not that of the lungs. They yield spirit to the left ventricle when the latter dilates and receive smokey vapours from it when it contracts.

To establish these points, Galen used a combination of theoretical argumentation and empirical demonstration. The lungs fill the entire capacity of the thorax and are passively dilated and contracted in response to its motions. The expansion of the thorax creates a vacuum which must be filled, and this could be accomplished by having all three vessels of the lung take in material and become distended. Thus when the lungs expand, external air would be drawn into the trachea, blood from the right cardiac ventricle into the pulmonary arteries, and a mixture of blood and air from the left ventricle into the pulmonary veins.

In fact, however, the latter two events are prevented from happening by two principles which control the suction of a vacuum: light material responds more readily than heavy, and material is drawn more easily through a larger opening than through a smaller one. The trachea has the largest orifice of all three vessels, and the material to which it has access, namely air, is lighter than that available to the other two vessels. Therefore when the lungs expand air will first be drawn into the trachea, and only when the latter vessel has reached its maximum distension will the mixture of air and blood be drawn into the pulmonary veins and blood into the pulmonary arteries. This means that the lungs would have to continue expanding after the trachea has been filled to capacity, but if the lungs of a dead animal are inflated through the trachea it can clearly be seen that the maximum distension of the lungs is coterminal with that of the trachea. Therefore the only result of the expansion and contraction of the thorax is the alternate filling and emptying of the trachea and its branches. The pulmonary arteries remain motionless, while the pulmonary veins dilate and contract in response to the motions of the left cardiac ventricle, not those of the lungs.

This passage is of some interest for the present discussion because in describing what would happen if the motions of the pulmonary veins were controlled by the lungs, Galen did say that blood would be drawn into these vessels from the left ventricle. Only when one reads the following discussion with some care does it become clear that he had presented this mechanism only to refute it. Thus it is possible that this statement influenced the widespread belief of later followers of Galen that blood does enter the pulmonary veins from the left ventricle. We have, however, found no evidence of such influence prior to the sixteenth century, long after the idea had become well established in the Galenic tradition on other grounds.

From late antiquity until the seventeenth century, most discussions of the heart and lungs by Byzantine, Arabic, and European writers were largely based, directly or indirectly, on Galen's De usu partium. Understandably, however, the preparation of these accounts generally involved considerable selection and condensation of Galen's rather lengthy arguments, and in particular his long and nuanced discussion of the two pulmonary vessels was commonly reduced to a few aphoristic statements. With respect to their views on the blood in the pulmonary veins, we may divide these later writers into three main groups: (1) those who made no reference at all to this blood; (2) those who did refer to this blood but did not indicate its source; (3) those who said that this blood comes from the left cardiac ventricle. Prior to the formulation of the concept of the pulmonary transit (among the Arabs by Ibn al-Nafis and among 


\section{The Chequered Career of Galen's Doctrine on the Pulmonary Veins}

Europeans by Servetus and Colombo), we know of no author who said that blood enters the pulmonary veins from the pulmonary arteries, and have found only three brief allusions of any kind (by Avicenna, Jean de St. Amand, and Fernel) to the doctrine of the pulmonary anastomoses. ${ }^{30}$

As was noted above, the assumption that the left ventricle is the chief source of arterial blood was probably an important reason for thinking that it is the source of the blood in the veinlike arteries (modern pulmonary veins) as well, although it was not until the later sixteenth century, in response to the discovery of the pulmonary circuit, that this argument was used explicitly. We have also called attention to a number of ambiguities within Galen's own discussion of the pulmonary vessels which lent further support to this view. The result was that once the idea that blood enters the pulmonary veins from the left ventricle was established, it endured in large measure because it seemed consistent with Galen's own doctrines rather than because later men simply failed to re-read what Galen himself had to say. Indeed, as we shall see, successive authorities actually embellished the idea with Galen's own words, especially by transferring statements which he made about the flow of blood from the right ventricle into the pulmonary artery, to the supposed flow of blood from the left ventricle into the pulmonary veins.

It is with Oribasius (326-403) that we find the first possible indication that the blood of the pulmonary veins comes from the left ventricle. Oribasius taught that the lungs ventilate the heat of the heart, providing cool air and removing smokey fumes, and also that they supply pneuma to the heart for distribution through the arteries, though he did not specify that these operations take place through the pulmonary veins. ${ }^{31}$ Instead, in his discussion of the two pulmonary vessels Oribasius focussed exclusively on their complementary roles in supplying two different kinds of nutritive blood to the lungs. ${ }^{32}$ The thicker blood of the pulmonary arteries comes from the right ventricle, but Oribasius did not clearly indicate the source of the thinner blood in the pulmonary veins. However, the derivation of this blood from the left ventricle can perhaps be inferred from the following passage:

In other parts of the body the tunics of the vessel[s] supplying blood [i.e., the veins] are light and thin, and so they readily supply a large amount of thick [blood] to the surrounding parts. But since [the tunics of the blood vessels] are thick in the lung, they allow only the light portion [of the blood] to escape. In other parts of the body the arteries were made thick and dense, and allow the surrounding parts to draw very little vaporous blood. To the lung alone do they release a large amount of such blood, which they are unable to retain because of their light substance. Thus as far as the nutrition of the lung is concerned, it is just the opposite of all the other parts of the animal, just as is the nature of its flesh. To ensure the abundance of such nutriment, it is sent to the lung from the heart, after the blood has been perfectly elaborated and attenuated in the latter organ. ${ }^{23}$

Except for the italicized clause, this entire passage was taken verbatim from the De usu partium. ${ }^{34}$ In the original, however, the last sentence is separated from the rest of the passage by several intervening sentences and from the context it seems clear

${ }^{30}$ See below.

31 Oribasius, Oeuvres, ed. and tr. Bussemaker and Daremberg, III, Paris, 1858, 326, 330, 331; see also $525-26$.

a2 Ibid., pp. 328, 333-35; see also p. 509.

Ibid., pp. 334-35.

se usu partium, VI, x; ed. Helmreich, I, 329-30. 


\section{J. J. Bylebyl and Walter Pagel}

that it refers to blood sent into the pulmonary artery by the right ventricle. As given by Oribasius it may in part apply to this blood, but because of the causal nexus which he added it seems to apply primarily to the blood of the pulmonary veins: the latter vessels, unlike the pulmonary arteries, supply a great deal of thin blood to the lungs, and in order to ensure the abundance of such blood, it is sent into the lungs by the heart. Oribasius himself may not have intended to imply that this blood comes from the left ventricle, but this might readily be inferred by someone who read this passage with no knowledge of Galen's view that this blood might reach the pulmonary veins indirectly from the right ventricle, via the pulmonary artery.

The Byzantine physician Theophilus Protospatarius (seventh century) said that the lung ventilates the heart by supplying cool air and removing fumes, again without making clear what role the pulmonary veins play in this process. ${ }^{35}$ But in Theophilus we find nothing at all about the reasons for the reversal of the tunics of the pulmonary vessels, the nutritive role of the pulmonary veins, or even the presence of blood in the latter vessels. Instead, we are simply told that the right ventricle supplies nutritive blood to the lungs through the pulmonary artery, while the lungs supply pneuma to the left ventricle and arteries through the pulmonary veins. ${ }^{38}$

The treatment of the pulmonary veins by Rhazes $(c .841-926)$ is similar to that of Theophilus except that there is not even a general reference to the elimination of smokey wastes by the lungs. ${ }^{37}$ The pulmonary artery conveys blood from the right ventricle of the heart to the lungs, while the pulmonary veins simply bring air from the lungs to the left ventricle.

In the Liber regius of Haly Abbas (d. 994) we find a more detailed discussion of the pulmonary veins, with due weight given to all three aspects of Galen's teachings about these vessels, namely that they ventilate the heart, supply air for distribution through the arteries, and supply an abundance of light arterial blood to the lungs. ${ }^{38}$ But in discussing the latter point, Haly Abbas stated explicitly, apparently for the first time, that this blood comes from the left ventricle. In part, this conclusion was perhaps motivated by his belief that in general the arteries 'contain blood sent by the heart [i.e., the left ventricle]', ${ }^{39}$ and this probably predisposed him to think that the blood of the veinlike arteries (modern pulmonary veins) is derived from the same source.

In addition, Haly Abbas made a significant simplification in Galen's ideas about the blood in the pulmonary artery. Galen had said that the blood in most of the veins throughout the body is 'thick and muddy' and that the vein of the lung was given the tunics of an artery to permit only the thinnest portion of its blood to escape, but he probably would have thought it inappropriate to call the blood of this arterylike vein 'thick and muddy' since it has already undergone considerable elaboration in the right ventricle. ${ }^{40}$ Haly Abbas, however, stated simply that the arterylike vein contains 'thick and muddy' blood, while the veinlike artery contains subtle blood and pneuma. ${ }^{11}$

${ }^{86}$ Theophilus Protospatarius, De corporis humani fabrica, tr. J. P. Crasso, Paris, 1556, pp. $42,43$. so Ibid., pp. 45, 48.

37 Rhazes, Livre al-Mansūri sur la médecine, tr. P. De Koning in Trois traités d'anatomie arabes, Leiden, 1903, pp. 61, 63, 65.

${ }_{38}$ Haly Abbas, Livre royal (al-malaki), tr. De. Koning in Trois traités, pp. 193, 323, $337-47$.

s9 Ibid., p. 191 .

4 See above, notes 15 and 17.

41 Haly Abbas, Livre royal, pp. 337-39. 


\section{The Chequered Career of Galen's Doctrine on the Pulmonary Veins}

Furthermore, he was the first of the writers under consideration to pay attention to Galen's teachings about the passage of blood from the right ventricle to the left through the cardiac septum, in particular to the idea that it is only the thinnest portion of the blood in the right ventricle that finds its way to the left. ${ }^{42}$ Thus the left ventricle contains thin blood, in contrast to the arterylike vein which contains 'thick and muddy' blood, and it is not difficult to see why it would have made more sense to Haly Abbas to suppose that the subtle blood of the veinlike artery comes from the former rather than the latter. ${ }^{43}$ As he summarized the situation, the veinlike artery 'is the vessel by which air passes from the lung to the heart, and blood from the heart to the lung'.44 It was probably from Haly Abbas that this idea entered the mainstream of the Galenic tradition.

Avicenna (980?-1037) likewise gave due recognition to all three functions which Galen attributed to the pulmonary veins, and he also shared the belief that the blood in these vessels comes from the left ventricle. ${ }^{45} \mathrm{He}$ stated that the veinlike artery arises from the left ventricle and branches through the lung,

in order to take up air and convey from the heart to the lung the blood which nourishes the lung, since the nourishment of the lung passes through the heart, and from the heart arrives at the lung ... [the veinlike artery] has been formed with a single tunic ... so that there can pass more easily into the lung the subtle and vaporous blood which is suitable for the substance of the lung, and which has attained perfect maturity in the heart, having no need for further perfection, as does the blood contained in the vena cava. ${ }^{16}$

These statements clearly echo similar ones made by Galen about the role of the heart in preparing nutriment for the lungs, but which Galen meant to apply to the right ventricle and pulmonary artery. ${ }^{47}$ Now Avicenna seems to think that the main pathway by which blood reaches the lungs is from the right ventricle through the cardiac septum to the left ventricle, and into the pulmonary veins. He did, however, note that the pulmonary artery also supplies nutritive blood to the lungs, and said that this vessel had to have thick tunics because the blood which it receives from the right ventricle is not yet as perfect as that supplied to the pulmonary veins by the heart (i.e., the left ventricle). ${ }^{48}$

Avicenna also added a further twist. In describing the mitral valve, he stated that 'the veinlike artery has two membranes which face inward. It has only two since it is not necessary for this orifice to close perfectly, as it is [for the aortic orifice]. On the contrary, here there is need of a lax closing so that the fuliginous vapour and the blood which flows to the lung can be expelled easily' [our italics]. ${ }^{49}$ Thus Galen's original statement that the mitral valve closes imperfectly to let the fumes escape has been amended to make allowance for the passage of blood from the left ventricle into the pulmonary veins as well.

Although Avicenna was quite clear concerning the origin of the blood in the pul-

¿2 Galen, On the natural faculties, III, xv; tr. Brock, p. 321.

4s Haly Abbas, Livre royal, pp. 345-49.

« Ibid., p. 347.

4s Avicenna, Canon, tr. De Koning in Trois traités, pp. 602-4, 682.

16 Ibid., pp. 602-4.

17 See above, note 17.

¿Avicenna, Canon, pp. 624-26.

4 Ibid., p. 606. 


\section{J. J. Bylebyl and Walter Pagel}

monary veins from the left ventricle, he did make an additional statement about the vessels of the lungs that is of some interest:

As far as the ramification of the vessels and of the trachea in the lung is concerned, the trachea and the veinlike artery [modern pulmonary vein] are connected in order to complete the action of respiration [i.e., to bring air from the lungs to the heart], while the veinlike artery and arterylike vein are connected in order to nourish the lung with the pure and elaborated blood which comes from the heart. ${ }^{\text {so }}$

There is no further explanation of the last statement, and by itself it makes little sense. But when it is considered in the light of the De usu partium it seems clear that it is a reference to the Galenic pulmonary anastomoses. It is interesting to note that this clause did not appear in the standard Latin translation of the Canon by Gerard of Cremona, though it was restored in the revised translation by Andrea Alpago published in $1527 . .^{51}$

Unlike Haly Abbas and Avicenna, Averroes (1126-1198) did not clearly specify the source of the blood in the pulmonary veins, though he seems to imply that it comes from the left ventricle. The artery extending from the left ventricle to the lungs has only one tunic, he explained,

so that it would be soft and lax for dilatation and contraction, for the attraction of air and the expulsion of smoky fumes. But it is larger [than other arteries] so that it can supply to the lungs blood which is subtle, vaporous, and close to perfection in digestion, because it is the heart which nourishes the lungs. 52

Once again we can discern a transfer of elements from Galen's description of the pulmonary artery to the pulmonary veins, since according to Galen it is the former vessel which is unusually large and conveys elaborated blood from the heart to the lungs. ${ }^{53}$

Before concluding this discussion of the Arabic physicians, we should note that it was an Arab of the thirteenth century, Ibn al-Nafis, who first conceived of the pulmonary transit as a pathway from the right ventricle to the left, in place of the Galenic pores through the septum. In presenting this idea Ibn al-Nafis assumed the existence of connections between the two pulmonary vessels, and it seems likely that he derived this idea from Galen, either directly from the De usu partium, or indirectly from the brief reference in the Canon of Avicenna. ${ }^{54}$ There is, however, still no evidence that his idea became known in Europe and therefore we shall assume that its rediscovery during the sixteenth century was independent.

The medieval Latin physicians derived their knowledge of Galenic anatomy and physiology largely from the Arabic authorities rather than directly from Galen, and a number of them followed the Arabs in assuming that the blood of the pulmonary

so Ibid., p. 682: 'l'artère veineuse et la veine artérieuse s'associent pour nourrir le poumon du sang élaboré et clair qui vient du coeur.'

61 Avicenna, Liber canonis, Venice, 1507, III, x, tr. i, cap. i, fol. 239 v: 'canna \& arteria venalis communicant in nutriendo pulmonem ex sanguine digesto claro veniente ex corde.' Avicenna, Liber canonis medicine. Cum castigationibus Andreae Bellunensis, Venice, 1527, fol. 189v: "canna \& arteria venalis communicant [in complemento operationis anhelitus, \& arteria venalis \& vena arterialis communicant] in nutriendo pulmonem ex sanguine digesto claro veniente ex corde.'

${ }^{32}$ Averroes, Colliget, Lyons, 1531, I, v, fol. 5v; see also II, ix, fol. 24r.

58 See above, note 16.

se See Wilson, 'The problem', pp. 231-32, and Siegel, 'Galen's doctrine', pp. 317-19, where they both suggest that Ibn al-Nafis was influenced by the De usu partium. 


\section{The Chequered Career of Galen's Doctrine on the Pulmonary Veins}

veins comes from the left ventricle. The idea that this blood comes from the pulmonary arteries was, however, potentially available during the middle ages. The complete De usu partium was not generally available in Latin until the early sixteenth century (though it had been translated two centuries earlier), but from at least the thirteenth century a condensed version known as De juvamentis membrorum was widely circulated. ${ }^{55}$ This version is quite corrupt in many respects, but it does refer to 'vias strictas' through which blood is squeezed from veins to arteries during the contraction of the thorax, though it is not entirely clear in this account that the vessels involved are specifically those of the lungs. ${ }^{56}$ Jean de St. Amand (thirteenth century) repeated this statement from the De juvamentis but gave no indication at all that the vessels in question are those of the lungs. ${ }^{57}$ Otherwise this passage seems to have been ignored during the middle ages. Perhaps this was partly because the De juvamentis was counterbalanced by another treatise, De anatomia vivorum, attributed to Galen but recognized as spurious by the early sixteenth century, where it is stated that the pulmonary veins carry air from the lungs to the left ventricle and nutritive blood from the left ventricle to the lungs. ${ }^{58}$

For most medieval Latin authors, however, the Canon of Avicenna was probably the main source of the idea that arterial blood enters the pulmonary veins from the left ventricle. Albertus Magnus (1193?-1280) clearly followed Avicenna on this point, as in most of his discussion of the heart. ${ }^{59}$ Pietro d'Abano (c. 1250-1315) referred to the De juvamentis membrorum as the source of the idea that the pulmonary veins supply the lungs with subtle blood, but cited Avicenna in support of the derivation of this blood from the left ventricle. ${ }^{60}$ Pietro's contemporary Henri de Mondeville may also have taken the latter idea from Avicenna, but he thought that there was justification for it in the De juvamentis itself. He stated that the pulmonary veins bring blood from the heart for the nutrition of the lungs, 'as Galen said in book six, chapter two of the De juvamentis membrorum: "We find that the heart is so indebted to the lung on account of the benefit of the air which it receives from it that it gives to [the lung] for its nutrition some of the same blood by which it is nourished".'61 Galen himself did make a similar statement in the original De usu partium, but it seems fairly clear in both versions that it refers to the supply of blood to the lungs through

${ }_{55}$ Donald Campbell, Arabian Medicine and its Influence on the Middle Ages, 2 vols., London, 1926, II, 41-44, lists only four manuscript copies of the complete $D e$ usu partium, but thirty of the De juvamentis membrorum. For a fuller discussion of the various Latin versions of the De usu partium, see the doctoral dissertation of Emilie S. Smith, 'Galen on nerves, veins and arteries', University of Wisconsin, 1969, pp. 29-38.

${ }^{56}$ De juvamentis membrorum, VII, iii, in Opera Galeni, 2 vols., Venice, 1490, I, fol. $26 r$.

57 Julius Pagel (ed.), Die Concordanciae des Johannes de Sancto Amando, Berlin, 1894, p. 361, especially: 'Vena non pulsatilis non habet orificium ad pectus ut pertranseat sanguis ex ea ad venas pulsatiles ex viis parvis in hora contractionis pectoris (ibi [i.e., de juv. membr.]).' The wording of this statement is roughly the same as in the version of the De juvamentis we have used, except that the latter has 'apertum' rather than 'ad pectus'. Cf. Galen, De usu partium, VI, x; tr. May, p. 303: 'But if the large orifice of the arterial vein [a. pulmonaris] always lay uniformly open, ... the blood would never be taken over into the arteries through the little, invisible orifices when the thorax contracts.'

${ }^{6}$ De anatomia vivorum in Galeno ascripti libri varia, Venice, 1561, fol. $47 r$.

59 Albertus Magnus, De animalibus libri xxvi, ed. Hermann Stadler, 2 vols, Münster, 1916-1920, I, 136.

${ }^{\circ}$ Pietro d'Abano, Conciliator, Venice, 1565, Diff. XXXI, prop. iii, fol. 49r.

-1 Julius Pagel (ed.), Die Chirurgie des Heinrich von Mondeville, Berlin, 1892, p. 46. 


\section{J. J. Bylebyl and Walter Pagel}

the pulmonary artery, in exchange for the air supplied to the heart through the pulmonary veins. ${ }^{62}$

Mondino da Luzzi (c. 1275-1326) and Guy de Chauliac (c. 1300-c. 1368) went to the opposite extreme of completely ignoring the nutritive function of the pulmonary veins. According to both men, the pulmonary artery supplies nutritive blood to the lungs, while the pulmonary veins supply air to the left ventricle and remove smokey fumes. ${ }^{63}$ In view of the influence of Mondino's Anatomia and Guy's Chirurgia during the next few centuries, their failure to make any reference at all to the presence of blood in the pulmonary veins was of some significance.

In the early sixteenth century Gabriele Zerbi (1445-1505) criticized Mondino for having failed to mention the flow of arterial blood from the left ventricle into the pulmonary veins. ${ }^{64}$ In his Commentary on Mondino Berengario da Carpi (c. 1460c. 1530) likewise referred to the latter idea, ${ }^{65}$ though in his Isagoge he added a new element to the discussion of the purpose of this blood. Previous discussions had generally centred on Galen's teaching that this blood serves the nutrition of the lungs, but in the later Galenic system the main purpose of arterial blood generally was not to serve as nutriment, but to sustain life. Thus Berengario brought the veinlike artery into conformity with the rest of the arterial system when he said that the main purpose of the blood in this vessel is not to nourish the lungs, as is commonly thought, but to vivify them. ${ }^{66}$ Nicolo Massa (1485-1569) held to the older view, for he stated that while most of the arterial blood of the left ventricle is converted into spirit, the pulmonary veins take up from the left ventricle 'the thicker part of the subtle blood which is not converted into spirit, for the nutrition of the lungs' ${ }^{67}$

Beginning in the 1520 s, humanist physicians made a concerted effort to purge Galenic anatomy and physiology of Arabist corruptions by relying only on Galen's original writings. This resulted in some improvement in the understanding of Galen's doctrines, including the recognition that Galen's descriptions of a flow of elaborated blood from the heart to the lungs referred to the blood expelled into the pulmonary artery by the right ventricle. However, Galen's description of a passage of blood from the pulmonary arteries to the pulmonary veins continued to be ignored. The only partial break in this silence about the pulmonary anastomoses during the first half

'see above, note 11 .

os Mondino, De omnibus humani corporis interioribus membris anathomia, ed. Johannes Adelphus, Strassburg, 1513, fol. 24v; Guy de Chauliac, La Grande Chirurgie, ed. E. Nicaise, I, Paris, $1890,56$.

os Gabriele Zerbi, Liber anathomie corporis humani, Venice, 1502, fol. 65v; see also fols. 69r and $71 v$. On $71 v-72 v$ he cites both Haly Abbas and Avicenna on this point.

os Jacopo Berengario da Carpi, Commentaria cum amplissimis additionibus super anatomia Mundini, Bologna, 1521, fols. 354v (where he cites Haly Abbas on this point), 355v-356r. On fol. 356r he states that according to Galen the arterylike veins (modern pulmonary arteries) 'non solum . . . nutriunt pulmonem: sed ... etiam arteriae eum nutriunt mediante sanguine in eis contento.' This is possibly a reference to Galen's pulmonary anastomoses, but more likely refers to De usu partium VII, viii, tr. May pp. 345-47, where Galen states that the arterylike veins provide nourishment for the rough artery (trachea) and its branches.

- Jacopo Berengario da Carpi, Isagoge breves perlucide ac uberime in anatomiam humani corporis, Bologna, 1522, fol. $34 r$ : 'Arteria venalis . . . aerem ad cor ducit: $\&$ educit/in ista est etiam spirituosus sanguis: ut aliquibus placet/ etiam pulmonem nutriens/magis tamen eum vitalitans/sui rami uniuntur seu coastomantur cum ramis tracheae: per quos pulmo cordi aerem dat/cor vero non ingratum/ vitam ei \& nutritionem donat.'

${ }^{67}$ Nicold Massa, Liber introductorius anatomiae, Venice, 1536, fol. 56r: 'Et etiam [arteria venalis] ducit sanguinem seu partem crassiorem sanguinis subtilis non conversam in spiritum, ad nutriendum pulmonem, in quo arteriae venalis orificio sunt duo tantum, hostiola. . . ? 


\section{The Chequered Career of Galen's Doctrine on the Pulmonary Veins}

of the sixteenth century, apart from that in Alpago's translation of the Canon (1527), seems to occur in the Physiologia of Jean Fernel (1497-1558). Here he denied that there are any connections between the extreme branches of the pulmonary vessels without acknowledging that he was thereby contradicting Galen, though from the context it appears that the contradiction was deliberate. ${ }^{68}$. Fernel, and similarly Jacobus Sylvius (1478-1555) and Charles Estienne (1504-1564), held that the left ventricle inhales air and exhales fumes through the pulmonary veins, without even mentioning the presence of blood in the latter. ${ }^{69}$ Matthew Curtius (c. 1475-c. 1544), on the other hand, followed Galen in holding that the pulmonary veins also supply an abundance of blood to the lungs, but he did not indicate the source of this blood. ${ }^{70}$

Johann Guinter of Andernach (1497-1574) primarily emphasized the respiratory functions of the pulmonary veins, ${ }^{71}$ though he also referred to a flow of blood into them from the left ventricle. ${ }^{72}$ From the context it seems clear that he was led to accept the latter idea as authentically Galenic by the passage in book seven of the De usu partium where Galen mentioned the possibility of such a flow, but then (we believe) went on to reject it. ${ }^{78}$ It is not clear to what extent Guinter was familiar with earlier anatomical writings other than those of Galen and therefore it is not possible to say whether this Galenic passage was the direct source of the idea for him or merely provided confirmation for what he already believed. In any case it seems likely that it was the branding of this doctrine as genuinely Galenic by Guinter that led to its acceptance by his student Vesalius, and in turn the endorsement of the idea in the Fabrica was probably of major significance in ensuring its persistence during the sixteenth and early seventeenth centuries. ${ }^{74}$ For Vesalius and others of this period, however, the assumption that the left cardiac ventricle is the unique source of arterial blood probably continued to be an important, perhaps the most important, rationale for the belief that it is the source of the blood in the veinlike arteries. ${ }^{75}$

- Jean Fernel, De naturali parte medicinae, Venice, 1547, fol. 221: 'Eo autem ordine collocata sunt tria haec vasa, ut aspera arteria ubique media inter levem arteriam atque venam [arterialem] interposita cernatur: non haec quidem extremis sese copulant \& continuantur.' This immediately follows a statement that during contraction of the lung blood cannot be squeezed from the pulmonary artery back to the right ventricle, but is extruded into the flesh of the lungs as nutriment. This clearly resembles the passage where Galen described the pulmonary anastomoses, and therefore it seems likely that Fernel consciously disagreed with him on this point.

0 Ibid., fols. 37v-38v, 57r, 220v-221v; Jacobus Sylvius, In Hippocratis \& Galeni physiologiae partem anatomicam isagogae, Venice, 1556, fol. 89; Charles Estienne, De dissectione partium corporis humani libri tres, Paris, 1545, pp. 211, 214-17, $219-20$.

${ }^{70}$ Matthaeus Curtius, In Mundini anatomen commentarius, Lyons, 1551, p. 360 . On p. 349 he does refer to a flow of blood from the heart into the 'venalis arteria' but from the context it appears that this is an error for 'arterialis vena'.

${ }^{11}$ Johann Guinter of Andernach, Institutionum anatomicarum secundum Galeni sententiam ... libri quatuor, Basle, 1536, pp. 79, 84-86, 89.

72 Ibid., pp. 91-92.

"See above, note 29 . Guinter's statement that the pulmonary veins convey blood from the heart to the lungs is immediately followed by a brief paraphrase of this Galenic passage, in which Guinter states that the dilation of the thorax draws blood out of the heart.

"Andreas Vesalius, De humani corporis fabrica, Basle, 1543, pp. 569, 595, 596, 598. See also Capivaccio, De anatomica methodo, p. 181; Caspar Bauhin, Theatrum anatomicum, Frankfurt, 1605, pp. 431-32; Johannes Alstedius, Theologia naturalis, n.p., 1615, p. 587. See also below on Piccolomini, Laurentius and Riolan. Most of these men seem to assume that the idea is authentically Galenic. The first to question this was apparently Caspar Hofmann, De Thorace, Frankfurt, 1627, p. 95, where he stated that earlier men have accepted the flow of arterial blood from the left ventricle to the pulmonary veins 'nimis quam inconsulto'.

15 See below on Piccolomini and Laurentius, who explicitly argued that the blood of the pulmonary veins must come from the left ventricle because the latter is the source of all arterial blood. 


\section{J. J. Bylebyl and Walter Pagel}

Vesalius also added further embellishments to this idea. In the passage quoted at the beginning of this paper he stated that the blood of the pulmonary veins has been concocted in both ventricles of the heart and therefore has the requisite thinness for nourishing the lungs, whereas the blood of the pulmonary arteries has been elaborated only by the right ventricle and therefore must undergo additional preparation in the lungs before it can be absorbed by the latter. Elsewhere he explained that the pulmonary veins supply the lungs with an abundance of spirituous blood, thereby compensating for what is denied to them because of the density of the tunics of the pulmonary arteries and the thickness of the blood contained by the latter. ${ }^{76}$ It is important to emphasize, however, that for Vesalius and many other men of the later sixteenth and early seventeenth centuries the respiratory functions of the pulmonary veins were still more important than the nutritive. ${ }^{77}$ Indeed, as late as 1615 Hieronymus Fabricius could still treat these vessels simply as ventilating ducts for the left ventricle without even mentioning that they also contain blood. ${ }^{78}$

Thus although it might be argued that Galen's original views about the pulmonary veins were conducive to the idea of the pulmonary transit, this was not true of the interpretation of Galen generally current during the sixteenth and earlier centuries. It would seem, then, that if Galen's description of the pulmonary anastomoses were to have influenced this discovery, it could only have been as a result of a careful reconsideration of the De usu partium itself. In the case of Michael Servetus this was almost certainly a factor, since he clearly had a direct and detailed familiarity with the De usu partium and based the pulmonary transit on the presumed existence of connections between the branches of the two pulmonary vessels. ${ }^{79}$ Furthermore, he explicitly invited the reader to compare his views with those in books six and seven of the De usu partium, where they would see that the truth had not been 'noticed (animadversam)' by Galen. ${ }^{80} \mathrm{He}$ perhaps meant to imply that although Galen had described the pulmonary anastomoses, he had not 'noticed' that they might form part of a pathway from the right ventricle to the left.

In the case of Realdo Colombo, ${ }^{81}$ on the other hand, there seems to be no clear evidence of detailed familiarity with books six and seven of the De usu partium. ${ }^{82}$ Moreover, unlike Ibn al-Nafis and Servetus, Colombo made no reference to direct connections between the pulmonary arteries and veins as part of the pulmonary transit. ${ }^{83}$ Thus it seems quite possible that he actually made the discovery entirely

70 Vesalius, Fabrica, 1543, p. 598.

17 Vesalius made frequent references to the respiratory functions of the pulmonary veins in the Fabrica: pp. 257 bis, 312 bis, 569, 582, 583, 590, 595, 598. In the Epitome, Basle, 1543, cap. iv, he did not mention the presence of blood in the pulmonary veins.

${ }_{78}$ Hieronymus Fabricius, De respiratione et eius instrumentis, Padua, 1615, pp. 14-15, 26-30, 33-35, 108-10.

70 Wilson, 'The problem', pp. 229-40; Siegel, 'Galen's doctrines', pp. 319-23.

${ }^{80}$ Michael Servetus, Christianismi restitutio (Murr reprint of 1791), p. 171.

81 This discussion of Colombo's work and the reaction to it is based on Bylebyl's doctoral dissertation, 'Cardiovascular physiology in the sixteenth and early seventeenth centuries', Yale University, 1969 , pp. 159-82, 300-402.

82 Realdo Colombo, De re anatomica, Venice, 1559, pp. 175-87, 222-24. His discussion of the heart is admittedly saturated with Galenic doctrines, but these do not appear to include any that could not have been derived from secondary sources such as the Fabrica, where no reference is made to the pulmonary anastomoses.

${ }_{83}$ Ibid., pp. 117, 223. 


\section{The Chequered Career of Galen's Doctrine on the Pulmonary Veins}

through his own observations, independently of Galenic influence. ${ }^{84}$ It was probably inevitable, however, that other men should point to a possible relationship between Galen's views and those of Colombo once the latter became well known. This was apparently done for the first time in 1578 by François Umeau, who gave Colombo credit for the concept of the pulmonary transit, but said that Galen himself had previously 'indicated' the idea when he said that the veinlike arteries 'take up a certain portion of blood from the arterylike veins through subtle and invisible passages' ${ }^{85}$

One would have thought that the possibility of attributing the pulmonary transit to Galen himself might have smoothed the way for its general acceptance by his followers, but this is not what happened. Colombo not only failed to cite Galen in support of his discovery, but presented the latter in strongly anti-Galenic terms. ${ }^{86}$ $\mathrm{He}$ particularly emphasized that it is primarily in the lungs, rather than the left ventricle of the heart, that venous blood is converted to arterial blood and endowed with the power to sustain life. In support of this view he argued that if the blood of the pulmonary veins passes from the lungs to the heart and only acquires its vivifying powers in the left ventricle, then the lungs would be the only parts of the body which somehow survive without a supply of vital blood, which would be absurd.

A number of men simply accepted the pulmonary transit without making this further change regarding the source of vital blood, but others felt compelled to come to grips with the problem of how the lungs could survive without arterial blood and vital spirits. Giulio Cesare Aranzi, for example, accepted the pulmonary transit as a replacement for the pores through the cardiac septum but also allowed for a reverse flow of vital spirit from the left ventricle to the pulmonary veins in order to avoid having to say either that vital spirits are generated in the lungs or that the latter do not receive a supply of vital spirits. ${ }^{87}$ Archangelo Piccolomini and Andreas Laurentius completely rejected Colombo's idea in favour of the Galenic pores through the septum. ${ }^{88}$ They maintained that vital blood is formed only in the left ventricle, and then used the reverse of Colombo's own argument to show that as a matter of theoretical necessity the blood in the pulmonary veins must come from the left ventricle or else the lungs could not remain alive. ${ }^{89}$ They even sought to prove that the pulmonary transit is completely impossible on the grounds that there are no anastomoses between the two pulmonary vessels!90 Thus, ironically, Galen's staunchest defenders contradicted him on this point in order to save another 'Galenic' doctrine of doubtful authenticity, namely the derivation of all arterial blood from the left ventricle of the heart.

Puzzlement has been expressed over the fact that in seeking to establish the pulmonary transit in the De motu cordis, William Harvey relied on Galen's authority rather

\footnotetext{
${ }^{84}$ See ibid., pp. 178, 224, where Colombo himself insists on the primary importance of vivisectional evidence in support of his view.

${ }^{85}$ François Umeau, De liene libellus, Paris, 1578, fol. 20 r.

${ }^{86}$ Colombo, De re anatomica, pp. 178-79, 223-24.

87 Giulio Cesare Aranzi, Anatomicae observationes, published together with the third edition of his De humano foetu liber, Venice, 1587, pp. 92-96.

88 Archangelo Piccolomini, Anatomicae praelectiones, Rome, 1586, pp. 222, 241; Andreas Laurentius, Historia anatomica, Frankfurt, 1599, pp. 358-61.

${ }^{80}$ Piccolomini, p. 221 ; Laurentius, pp. 360, 374-75.

${ }_{90}$ Piccolomini, pp. 238, 241; Laurentius, pp. 374-75. The same argument was used against Colombo by Caspar Bauhin, Theatrum anatomicum, Frankfurt, 1605, p. 461.
} 


\section{J. J. Bylebyl and Walter Pagel}

than experimental demonstration..$^{91}$ However, when viewed against this background his approach becomes quite understandable. As Harvey himself said, those who would be swayed to accept the pulmonary transit on the basis of demonstration had already been convinced by Colombo, so that further demonstrations would be superfluous.92 'Since, however, there are some who defer only to duly adduced authorities, let them know that this truth [the pulmonary transit] can be established from Galen's own words'. Harvey then quoted Galen's description of the pulmonary anastomoses and tried to show that the pulmonary transit is a necessary consequence of this and other Galenic doctrines. He was quite careful, however, not to say that Galen himself had actually conceived of the pulmonary transit as such (he attributed the idea to Colombo), but simply maintained that this idea could be deduced from Galen's own teachings and observations-some of which had been ignored by his followers over the preceding ages.

As a postscript to this study it is interesting to consider the position of Jean Riolan II (1580-1657), 'the last great humanist and Galenist of the Paris medical school'.93 In his Anthropographia (1618) Riolan stated, 'The veinlike artery [modern pulmonary vein] has a triple use, namely to bring inspired air into the heart, to remove the wastes from the vital spirits, that is, the fuligines, and to supply arterial blood to the lungs'. ${ }^{94}$ He further maintained that blood enters the left ventricle by passing through the cardiac septum from the right, and rejected the pulmonary transit. ${ }^{95}$ But by the time of his Encheiridium (1649) he had reluctantly begun to give way on all of these points, as on so many others, in the face of Harvey's work: '[the veinlike artery] brings blood from the lungs to the left ventricle of the heart, according to the doctrine of some [his italics], or conveys air prepared in the lung to this ventricle, and at the same time removes the fuligines, though the latter function is rejected by many'.98 Riolan himself still held that blood reaches the left ventricle primarily by passing through the septum, 'though I do not deny that in violent agitation of the heart and lungs it passes by way of the lungs'. ${ }^{97}$ Thus his capitulation on these points was only partial, except on the idea that the pulmonary vein supplies blood to the lungs, of which he made no mention in the Encheiridium.

\section{CONCLUSION}

(1) Galen regarded the pulmonary vein primarily as a ventilating tube for the heart, leading air in and smokey products of combustion out; some of this air is distributed to the arteries as pneuma.

91 Donald Fleming, 'William Harvey and the pulmonary circulation', Isis, 1955, 46, 319-27. Fleming comes to the rather dubious conclusion that Harvey's reliance on Galen's authority in support of the pulmonary circuit primarily reflects his indifference to the latter.

William Harvey, Movement of the heart and blood in animals, tr. K. J. Franklin, Everyman's library, London, 1966, p. 52. The discussion takes up most of chapter seven.

'a Nikolaus Mani, 'Jean Riolan II (1580-1657) and medical research', Bull. Hist. Med., 1968, 42, 144. See also pp. 121-28 on Riolan's attitudes toward Galen.

of Jean Riolan II, Anthropographia, Paris, 1618, p. 392. The same statement is made in the second edition, Paris, 1626, p. 367.

"Anthropographia, 1618, pp. 395-96; 1626, pp. 369-70.

'0 Riolan, Encheiridium anatomicum et pathologicum, Leyden, 1649, p. 224. See Mani, 'Riolan', pp. 128-44 for the more general modifications which he made in his views on cardiovascular physiology in reaction to Harvey.

on Encheiridium, p. 224. 


\section{The Chequered Career of Galen's Doctrine on the Pulmonary Veins}

(2) According to Galen, the pulmonary veins also contain arterial blood for the sake of the lungs, which are in need of it because of the insufficiency of that which is supplied to them by the thick-walled pulmonary artery.

(3) Galen probably considered the blood of the pulmonary veins to be derived from the thinner portion of the blood of the pulmonary arteries, which is forced through minute anastomoses between the fine ends of the two vessels by the motions of the lungs.

(4) In one passage Galen referred to the possibility of a movement of blood from the left ventricle into the pulmonary veins, but then went on to reject this possibility.

(5) In view of Galen's consistent emphasis on the idea that the blood of the pulmonary veins is consumed by the lungs as nutriment, there is no reason to assume that some of this blood passes on to the left auricle and ventricle or in other words that Galen was aware of the pulmonary transit as a pathway from the right cardiac ventricle to the left.

(6) Galenic commentators from Haly Abbas in the tenth century to the early seventeenth century generally agreed with Galen on points (1) and (2), but commonly assumed that arterial blood was sent into the pulmonary veins for the lungs from the left ventricle of the heart.

(7) This assumption seems to have stemmed from a misunderstanding of some of Galen's specific statements about the nutrition of the lungs, as well as from the general idea that the left ventricle of the heart is the only source of arterial blood.

(8) Galen's discussion of intrapulmonary anastomoses between the pulmonary arteries and veins was almost universally ignored prior to the discovery of the pulmonary transit and continued to be ignored even afterward by those who opposed the discovery as an anti-Galenic doctrine.

\section{ACKNOWLEDGEMENT}

The authors wish to thank Dr. C. R. S. Harris for help in many points of Galenic interpretation. 